\title{
(450) \\ Evaluation of the Electrocatalytic Activity of Antimony-Doped Tin Dioxide Anodes toward the Oxidation of Phenol in Aqueous Solutions
}

\author{
F. Montilla, ${ }^{\mathrm{b}}$ E. Morallón, ${ }^{\mathrm{a}, \mathrm{z}}$ and J. L. Vázquez ${ }^{\mathrm{a}}$ \\ ${ }^{a}$ Departamento de Química Física e Instituto Universitario de Materiales de Alicante, \\ Universidad de Alicante, Alicante E-03080, Spain \\ Instituto de Biología Molecular y Celular, Universidad Miguel Hernández \\ E-03202 Elche (Alicante), Spain
}

\begin{abstract}
Antimony-doped tin dioxide electrodes supported on titanium have been used in the electrochemical treatment of aqueous solution containing phenol. $\mathrm{Ti} / \mathrm{SnO}_{2}-\mathrm{Sb}$ anode has high efficiency in the elimination of phenol, but its use is hindered by its short service life. The introduction of platinum in the oxide layer ( 3 or 13 atom $\%$ ) increases the electrode service life up to two orders of magnitude. The electrocatalytic activity of the electrodes toward phenol oxidation has been analyzed with respect to the amount of platinum in the electrode composition. Voltammetric studies show that the oxidation potential of phenol decreases with the amount of platinum in the oxide layer. The activity for phenol oxidation per electroactive site is higher with the $\mathrm{Sb}^{-\mathrm{doped}} \mathrm{SnO} \mathrm{O}_{2}$ electrode within the zone of electrochemical stability of the solvent. Galvanostatic electrolysis of phenol solutions was performed analyzing several factors that affect the efficiency of the elimination process, such as anode composition, cell design, current density, and phenol concentration. The electrode containing platinum ( 3 atom \%) presents the highest efficiency for phenol removal, even higher than $\mathrm{Sb}$-doped $\mathrm{SnO}_{2}$.
\end{abstract}

(C) 2005 The Electrochemical Society. [DOI: 10.1149/1.2013047] All rights reserved.

Manuscript submitted February 14, 2005; revised manuscript received May 19, 2005. Available electronically August $25,2005$.

Electrochemical processes for wastewater treatment provide versatile methods for the removal of refractory organic pollutants. Anodic oxidation is a suitable technique either for the complete degradation of organic compounds (electrochemical incineration ${ }^{1,2}$ ) or for its transformation to nontoxic organic residues prior to the biological process. ${ }^{3}$ The last process should be preferred for wastewater treatments since the electrochemical incineration is a very expensive method compared with standard treatments.

Phenolic compounds are used in many chemical and pharmaceutical processes, and therefore are present in many industrial wastewater streams. The electrochemical oxidation is a feasible alternative for phenol removal from aqueous effluents. ${ }^{4-8}$ In addition, phenol electrolysis is a possible route for the synthesis of quinones. A main problem of the anodic behavior of phenol is the electrode fouling produced by polymerization of phenol. This problem can be overcome using high potentials for phenol oxidation.

The electrode material is a key factor for these processes and must fulfill the following requirements: (i) high efficiency in the organic oxidation, (ii) stability in anodic polarization conditions, and (iii) low production costs.

The most used anodes for organic oxidation in aqueous media are the so-called "nonactive" electrodes. These electrodes have high overvoltage for the oxygen evolution reaction (OER) and promote the oxidation of organic compounds by $\mathrm{OH}^{*}$ radicals that are present in high concentration near the electrode surface. ${ }^{10}$ Typical "nonactive" layers employed in water remediation are $\mathrm{PbO}_{2},{ }^{11,12}$ borondoped diamond (BDD), ${ }^{8,13,14}$ and $\mathrm{Sb}$-doped $\mathrm{SnO}_{2} .{ }^{15,16}$

Layers of antimony-doped $\mathrm{SnO}_{2}$ supported on titanium present a high performance in the anodic elimination of organic compounds in aqueous solutions, however its stability in such conditions is very low. The service life of $\mathrm{Ti} / \mathrm{SnO}_{2}-\mathrm{Sb}$ anodes is typically less than $12 \mathrm{~h}$ at $100 \mathrm{~mA} \mathrm{~cm}^{-2}$ for the electrolysis of aqueous acidic solutions. ${ }^{17,18}$ The main cause for the deactivation of these electrodes is the formation of a nonconductive tin hydroxide in the outer layer of the oxide. ${ }^{19-22}$

In order to increase the service life of the electrodes, the composition of the coating has been modified by the addition of platinum to the tin dioxide layer. This change in composition avoids the formation of the outer passive layer and increases the service life in several orders of magnitude. ${ }^{18,20}$ Platinum must be added in small

${ }^{\mathrm{z}}$ E-mail: morallon@ua.es amount in order to keep the electrocatalytic performance of the electrodes. When the amount of platinum in the oxide coating is around 13 atom $\%$, the electrocatalytic activity toward the oxygen evolution reaction (OER) is not strongly affected by the presence of platinum, and the variations of reactivity are more related to geometrical effects than to electronic changes. The electrocatalysis toward oxidation of organic compounds with simultaneous production of oxygen is narrowly bonded to the electrocatalysis toward OER because materials with high overpotential for OER have high activity for the oxidation of organic compounds. ${ }^{10,23,24}$ Several papers can be found in the literature concerning the oxidation of phenol and substituted phenol compounds which are usual test reactions employed to ensure the electrochemical capacity of doped tin dioxide anodes for their use in electrochemical remediation of wastewater. $6,15,19,23,25$

The aim of this work is to measure the effect of the presence of platinum in the electrocatalysis of Sb-doped tin dioxide electrodes toward the oxidation of phenol. The anodic oxidation of phenol is a test reaction for the application of these electrodes for environmental electrochemistry.

\section{Experimental}

The electrodes of tin dioxide were prepared by thermal decomposition of the salt precursor on a titanium substrate. The salt precursors were $\mathrm{SnCl}_{4} \cdot x 5 \mathrm{H}_{2} \mathrm{O}$ (Aldrich), $\mathrm{SbCl}_{3}$ (Fluka p.a.), and $\mathrm{H}_{2} \mathrm{PtCl}_{6}$ in a mixture ethanol (Merck p.a.) $+\mathrm{HCl}$ (Merck p.a.). Prior to the deposition process, the Ti support (plates of $7 \mathrm{~cm}^{2}$ for voltammetric measurements) was etched during $1 \mathrm{~h}$ in a solution of boiling oxalic acid (10\%). Ti/ $\mathrm{SnO}_{2}-\mathrm{Sb}$ electrodes were prepared using a solution containing $10 \% \mathrm{SnCl}_{4} \cdot x 5 \mathrm{H}_{2} \mathrm{O}+1 \% \mathrm{SbCl}_{3}$ and the electrodes containing platinum were prepared by adding to the previous solution a precursor of platinum. Two sets of electrodes were prepared by adding $\mathrm{H}_{2} \mathrm{PtCl}_{6} 0.4 \%$ in weight ( 3 atom \%) and $2.1 \%$ in weight $(13$ atom \%), respectively. The precursor solution was brushed on a Ti plate and the electrode was introduced in an oven at $400^{\circ} \mathrm{C}$ during $10 \mathrm{~min}$. This process was repeated 10,20 , and 30 times for attaining different film thickness. A final annealing was performed at $600^{\circ} \mathrm{C}$ for $1 \mathrm{~h}$. Details about the preparation method were described in a previous paper. ${ }^{20}$ At least three electrodes of each type have been prepared in this work and the data presented here are the average of at least three concordant measurements.

The aqueous $0.5 \mathrm{M} \mathrm{H}_{2} \mathrm{SO}_{4}$ solutions were prepared form Merck Suprapur. Phenol was from Merck p.a. and ultrapure water (Purelab Ultra from Elga-Vivendi, $18.2 \mathrm{M} \Omega \mathrm{cm}$ was employed for the preparation of the solutions. Potentials are referred to a reversible hydro- 


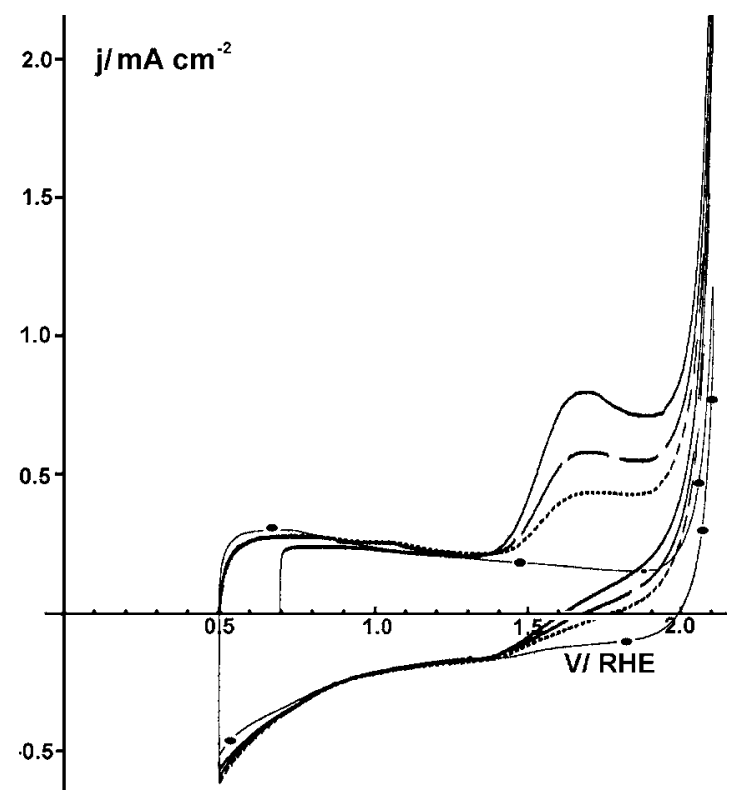

Figure 1. Cyclic voltammograms of a $\mathrm{Ti} / \mathrm{SnO}_{2}-\mathrm{Sb}$ electrode in a $0.5 \mathrm{M}$ $\mathrm{H}_{2} \mathrm{SO}_{4}+200 \mathrm{ppm}$ phenol solution. - first scan, - - - second scan, - - - - fifth scan. - - - voltammogram of the test solution obtained in the absence of the organic compound.

gen electrode (RHE) immersed in the same solution. Cyclic voltammograms were obtained at a constant sweep rate of $100 \mathrm{mV} \mathrm{s}^{-1}$. The current densities have been calculated using the geometric area of the electrodes $\left(7 \mathrm{~cm}^{2}\right)$.

Prior to electrochemical measurements, the electrodes of doped tin dioxide were pretreated anodically at $10 \mathrm{~mA} \mathrm{~cm}$-2 for $10 \mathrm{~min}$ in order to clean the surface and stabilize the oxide layer.

The electrolysis runs were performed in filter-press cells. The doped tin dioxide anodes were prepared by thermal decomposition on titanium expanded meshes (electrode area $20 \mathrm{~cm}^{2}$ ). The preparation method was similar to the process used for elaboration of plates. The electrolyte was introduced in a jacketed reservoir and was pumped through the reactor by means of centrifugal pumps. Phenol concentration and chemical oxygen demand (COD) were analyzed during the electrolysis by means of a Merck Spectroquant multianalyzer equipped with a Nova 60 photometer. The total organic carbon of the solution was analyzed with an AnalitikJena micro N/C total carbon and nitrogen analyzer [nonpurgeable organic carbon (NPOC) analyzer].

\section{Results and Discussion}

Cyclic voltammetry and potential step measurements.-Figure 1 shows the cyclic voltammograms for a $\mathrm{Ti} / \mathrm{SnO}_{2}-\mathrm{Sb}$ electrode in a $0.5 \mathrm{M} \mathrm{H}_{2} \mathrm{SO}_{4}$ solution containing $200 \mathrm{ppm}$ of phenol. In the first voltammetric scan, an oxidation peak appears centered at $1.70 \mathrm{~V}$ due to phenol oxidation (current density $j=796 \mu \mathrm{A} \mathrm{cm}^{-2}$ ). At potential more positive than $1.9 \mathrm{~V}$, the current rises due to OER. There is no remarkable process happening in the backward scan,

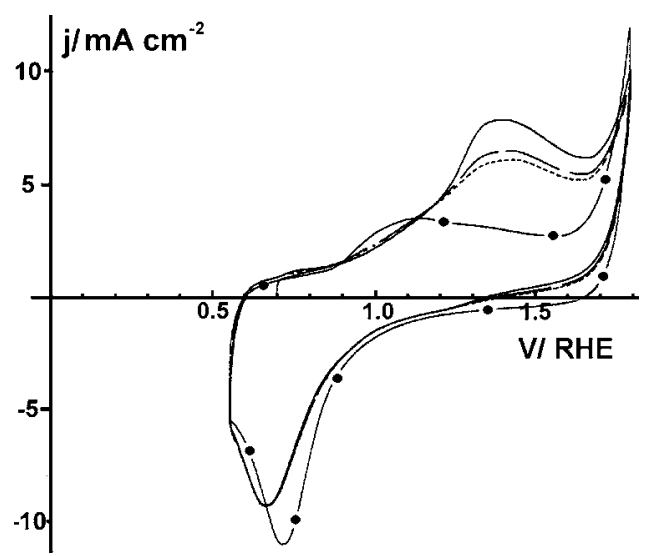

Figure 2. Cyclic voltammograms of a $\mathrm{Ti} / \mathrm{SnO}_{2}-\mathrm{Sb}-\mathrm{Pt}(13$ atom \%) electrode in a $0.5 \mathrm{M} \mathrm{H}_{2} \mathrm{SO}_{4}+200 \mathrm{ppm}$ phenol solution. — first scan, - - second scan, - - - - - fifth scan. - - - voltammogram of the test solution obtained in the absence of the organic compound.

indicating that phenol is irreversibly oxidized. An oxidation peak at $1.68 \mathrm{~V}$ appears in the second positive, but the current density of this peak is lower than that obtained in the first scan $\left(j=574 \mu \mathrm{Acm}^{-2}\right.$, degree of deactivation $28 \%$ ). The inhibition of the oxidation process is due to the electrode fouling produced by the formation of a nonconductive polymeric product coming from phenol oxidation. ${ }^{26}$ The successive scans are very similar and evidence the formation of a passive layer. The electrode surface can be restored by anodic polarization of the electrode at $10 \mathrm{~mA} \mathrm{~cm}{ }^{-2}$ for $10 \mathrm{~min}$.

Figure 2 shows the voltammograms of a platinum(13 atom \%)antimony-doped tin dioxide electrode in a $0.5 \mathrm{M} \mathrm{H}_{2} \mathrm{SO}_{4}$ solution containing $200 \mathrm{ppm}$ of phenol. In the first voltammetric scan, an oxidation peak appears at $1.38 \mathrm{~V}$ due to the oxidation of phenol $\left(j=7.82 \mathrm{~mA} \mathrm{~cm}^{-2}\right)$. In the successive scans, the oxidation of phenol is partially inhibited due to electrode fouling. The degree of deactivation in the second scan is $17 \%$. The oxidation potential of phenol on these $\mathrm{Ti} / \mathrm{SnO}_{2}$-Sb-Pt electrodes is the same as the oxidation potential of this compound on polycrystalline platinum, which indicates that phenol is mainly oxidized on platinum particles dispersed on the electrode surface. The oxidation peak of phenol on polycrystalline platinum appears at $1.38 \mathrm{~V}$, but the fouling process is stronger in the platinum electrode than in doped tin dioxide electrodes (voltammograms not shown).

A similar voltammogram was obtained with a $\mathrm{Ti} / \mathrm{SnO}_{2}-\mathrm{Sb}$ electrode doped with platinum 3 atom \% (figure not shown). The peak potential of phenol oxidation is $1.44 \mathrm{~V}$ and the current density is $1.50 \mathrm{~mA} \mathrm{~cm}{ }^{-2}$. The electrode surface can be restored by anodic polarization of the electrode at $10 \mathrm{~mA} \mathrm{~cm}{ }^{-2}$ for $10 \mathrm{~min}$.

Table I summarizes the voltammetric data obtained in the oxidation of phenol with these electrodes, including data of total voltammetric charge of the electrodes, $q_{T}^{*}$, which is related to the number of electroactive sites for charge transfer obtained as indicated in Ref.

\footnotetext{
Table I. Voltammetric data obtained from the oxidation of $200 \mathrm{ppm}$ phenol in $0.5 \mathrm{M} \mathrm{H}_{2} \mathrm{SO}_{4}$ with doped tin dioxide electrodes. Potential of phenol oxidation in the first voltammetric scan $(E)$, current density of the peak maximum $(j)$, voltammetric oxidation charge of phenol $(Q)$, total voltammetric charge of the electrode related to the total electroactive sites $\left(q_{T}^{*}\right)$, and activity per site $\left(Q / q_{T}^{*}\right)$.
}

\begin{tabular}{lcccrr}
\multicolumn{1}{c}{ Electrode } & $\begin{array}{c}E \\
\mathrm{~V}(\mathrm{RHE})\end{array}$ & $\begin{array}{c}j \\
\left(\mathrm{~mA} \mathrm{~cm}^{-2}\right)\end{array}$ & $\begin{array}{c}Q \\
\left(\mathrm{mC} \mathrm{cm}^{-2}\right)\end{array}$ & $\begin{array}{c}q_{T}^{*} \\
\left(\mathrm{mC} \mathrm{cm}^{-2}\right)\end{array}$ & $\begin{array}{c}\text { Activity per site } \\
\left(Q / q_{T}^{*}\right)\end{array}$ \\
\hline $\mathrm{Ti} / \mathrm{SnO}_{2}-\mathrm{Sb}$ & 1.68 & 0.796 & 5.78 & 2.55 & 2.27 \\
$\mathrm{Ti} / \mathrm{SnO}_{2}-\mathrm{Sb}-\mathrm{Pt}(3$ atom \%) & 1.44 & 1.50 & 6.61 & 4.99 & 1.33 \\
$\mathrm{Ti} / \mathrm{SnO}_{2}-\mathrm{Sb}-\mathrm{Pt}(13$ atom \%) & 1.38 & 7.82 & 11.15 & 17.11 & 0.65
\end{tabular}



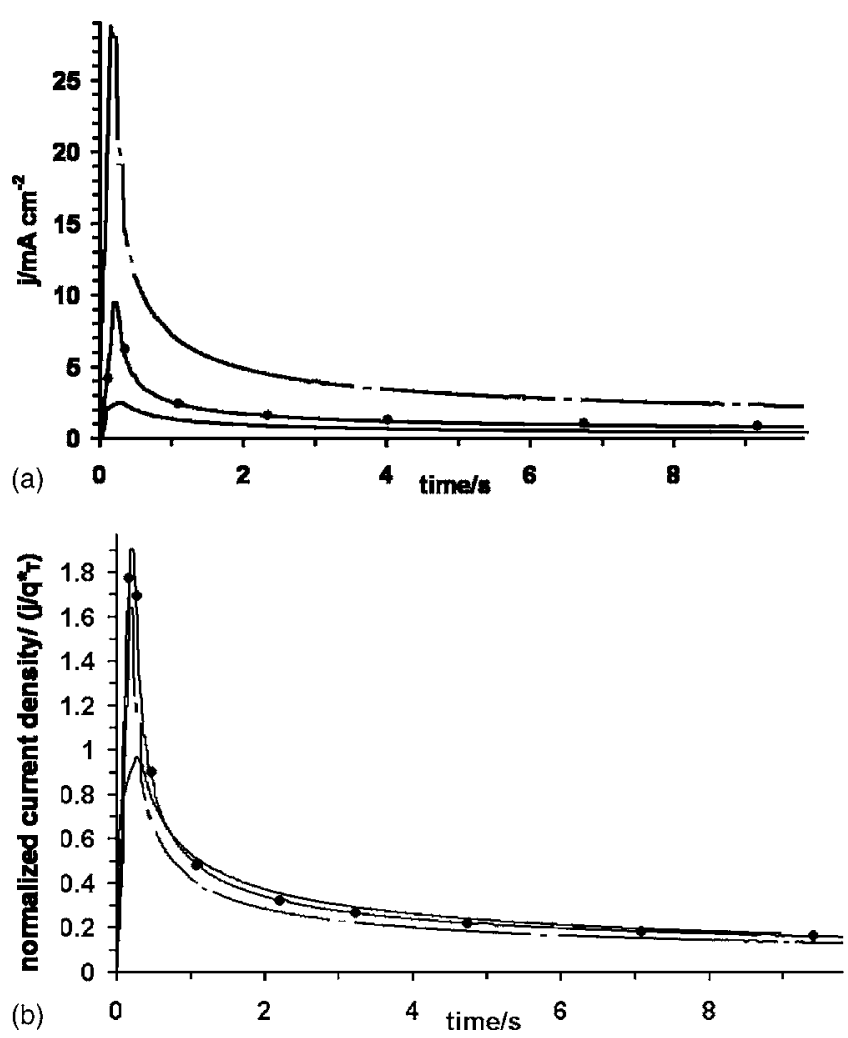

Figure 3. (a) Potential step measurements obtained during the oxidation of $200 \mathrm{ppm}$ of phenol in $0.5 \mathrm{M} \mathrm{H}_{2} \mathrm{SO}_{4}$ solution. —— $\mathrm{Ti} / \mathrm{SnO}_{2}-\mathrm{Sb}-\mathrm{Pt}(13$ atom $\%$ ) electrode, - - - Ti/SnO $\mathrm{Sn}_{2}-\mathrm{Sb}-\mathrm{Pt}(3$ atom \%) electrode, $\mathrm{Ti} / \mathrm{SnO}_{2}-\mathrm{Sb}$ electrode. (b) shows the normalized values of current density $\left(j / q_{T}^{*}\right)$. Initial potential $0.7 \mathrm{~V}$. Final potential $1.8 \mathrm{~V}$.

20, and the voltammetric oxidation charge due to phenol oxidation in the first voltammetric scan $(Q)$. As can be observed, the electrodes containing platinum have oxidation charges higher than electrodes without platinum. Note, however, that the voltammetric oxidation charge is referred to the apparent surface area of the electrodes. In order to consider the real electroactive surface, the values of oxidation charge $(Q)$ have been normalized with the total voltammetric charge $\left(q_{T}^{*}\right)$, and the values of activity per active site $\left(Q / q_{T}^{*}\right)$ are also presented in Table I. Attending to those data, electrodes of antimony-doped tin dioxide present higher activities for oxidation of phenol than electrodes doped with platinum.

In order to check the electrocatalytic activity of these electrodes, chronoamperometric experiments have been performed. Potential step experiments have been performed from an initial potential of $0.7 \mathrm{~V}$ (where no oxidation of phenol happens) to $1.8 \mathrm{~V}$; at this potential, the oxidation of phenol takes place in all the electrodes. Figure 3a shows the plot of the current density vs time for $\mathrm{Ti} / \mathrm{SnO}_{2}-\mathrm{Sb}$ and $\mathrm{Ti} / \mathrm{SnO}_{2}-\mathrm{Sb}$-Pt electrodes in a $200 \mathrm{ppm}$ phenol $+0.5 \mathrm{M} \mathrm{H}_{2} \mathrm{SO}_{4}$ solution. The shape of the transient curves is qualitatively very similar. After the relaxation of the double layer, the current related with faradaic reaction due to the oxidation of phenol in solution appears. In Fig. 3a, there are big differences in current densities due to different roughness factor and number of electroactive sites of the different electrodes. The real electrocatalytic activity can be properly compared by normalization of the values of current dividing the current by the total voltammetric charge related with the surface sites $\left(q_{T}^{*}\right)$. The normalized plots are shown in Fig. $3 \mathrm{~b}$. This figure shows that comparable plots are obtained, indicating that these electrodes present a similar mechanism for the oxidation of phenol by potentiostatic method.
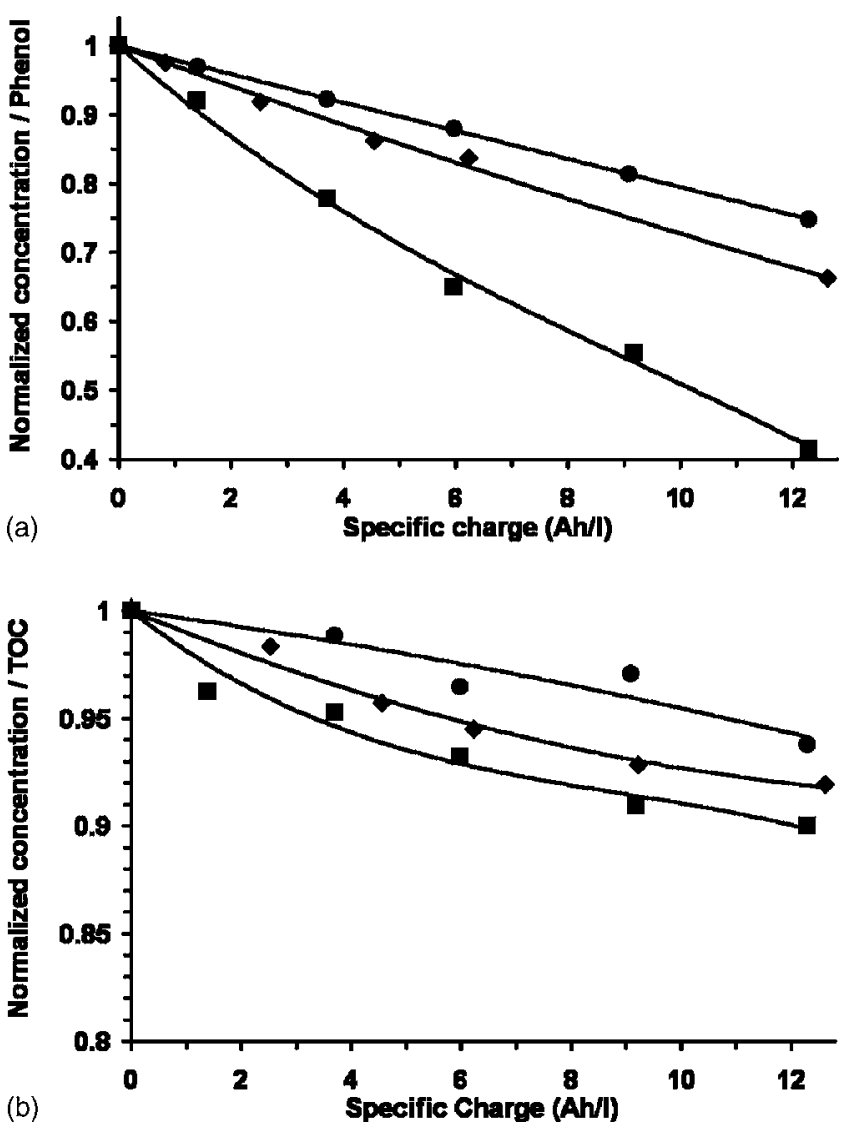

Figure 4. Evolution of the (a) normalized phenol concentration and (b) normalized total organic carbon (TOC) vs specific charge in the electrolysis of a $1000 \mathrm{ppm}$ phenol $+0.5 \mathrm{M} \mathrm{H}_{2} \mathrm{SO}_{4}$ solution in a single-compartment filter-press cell. Current density $25 \mathrm{~mA} \mathrm{~cm}^{-2}$. Cathode stainless steel. Rhombus points $(\bullet) \mathrm{Ti} / \mathrm{SnO}_{2}-\mathrm{Sb}$ anode, square points $(\square) \mathrm{Ti} / \mathrm{SnO}_{2}-\mathrm{Sb}-\mathrm{Pt}(3$ atom \%) anode, circle points $\left(-\mathrm{Ti} / \mathrm{SnO}_{2}-\mathrm{Sb}-\mathrm{Pt}(13\right.$ atom \%) anode.

Electrolysis runs.-Electrocatalytic activity of doped $\mathrm{SnO}_{2}$ anodes.- - In order to compare the electrocatalytic activity, the electrolysis of aqueous solution of phenol has been performed employing different doped $\mathrm{SnO}_{2}$ electrodes as anodes in a filter-press cell. The initial solution was $1000 \mathrm{ppm}$ phenol $+0.5 \mathrm{M} \mathrm{H}_{2} \mathrm{SO}_{4}$. During the electrolysis, the phenol concentration and the COD and total organic carbon were analyzed.

Figure 4 shows the evolution of phenol concentration and TOC with the charge during the electrolysis using a cell with a single compartment at a current density of $25 \mathrm{~mA} \mathrm{~cm}^{-2}$. Figure 4a shows the evolution of normalized phenol concentration (concentration divided by the initial concentration) during the electrolysis runs. As it can be observed, the electrode of $\mathrm{Ti} / \mathrm{SnO}_{2}-\mathrm{Sb}-\mathrm{Pt}(3 \%)$ presents the highest performance for phenol elimination and almost $60 \%$ of phenol concentration has decreased after $12 \mathrm{Ah} \mathrm{L}^{-1}$. This efficiency is better than that obtained with a $\mathrm{Ti} / \mathrm{SnO}_{2}-\mathrm{Sb}$ electrode without platinum. However the electrode doped with $\mathrm{Pt}(13 \%)$ has the lowest efficiency for phenol elimination.

Figure $4 \mathrm{~b}$ shows the evolution of the total organic carbon (TOC) during the electrolysis runs and a similar trend can be observed for the three electrodes studied. Taking into account that the solution flows in a cell with a single compartment and the oxidation products can be reduced in the cathode, this result indicates that phenol is oxidized on the anodes to species that can be reduced in the cathode (such as phenol oligomers or quinones) or refractory species toward 

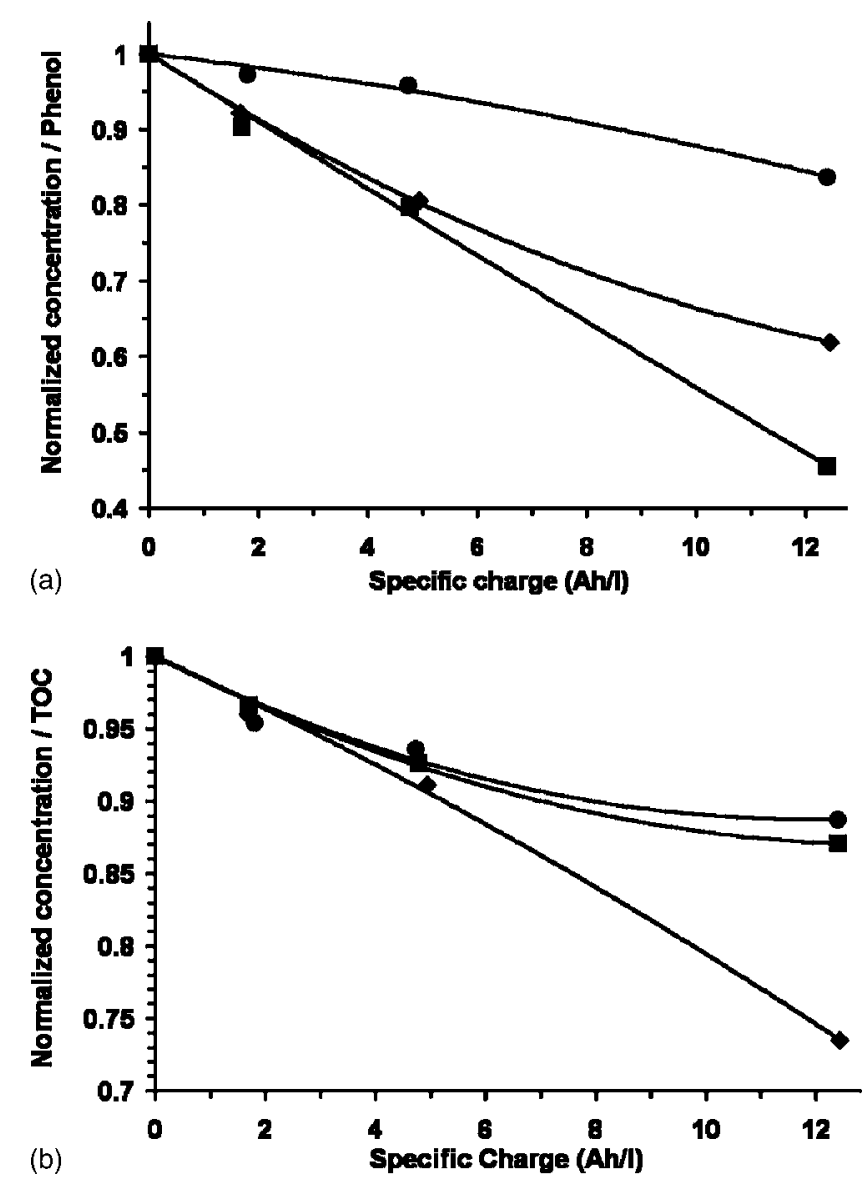

Figure 5. Evolution of the (a) normalized phenol concentration and (b) normalized total organic carbon (TOC) vs specific charge in the electrolysis of a $1000 \mathrm{ppm}$ phenol $+0.5 \mathrm{M} \mathrm{H}_{2} \mathrm{SO}_{4}$ solution in a two-compartment filterpress cell. Current density $25 \mathrm{~mA} \mathrm{~cm}^{-2}$. Cathode stainless steel. Rhombus points $(\diamond) \mathrm{Ti} / \mathrm{SnO}_{2}-\mathrm{Sb}$ anode, square points $(\square) \mathrm{Ti} / \mathrm{SnO}_{2}-\mathrm{Sb}-\mathrm{Pt}$ (3 atom $\%$ ) anode, circle points $\left(-\mathrm{Ti} / \mathrm{SnO}_{2}-\mathrm{Sb}-\mathrm{Pt}(13\right.$ atom \%) anode.

oxidation such as carboxylic acids. The reaction scheme would be $\mathrm{e}^{27}$

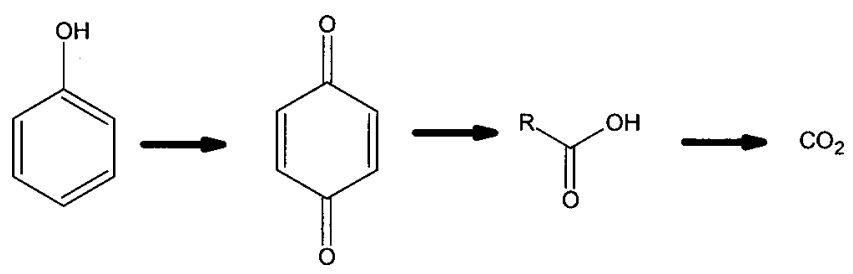

Benzoquinone formed in the initial oxidation steps can be reduced in the cathode to hydroquinone, decreasing the current efficiency for TOC removal.

The amount of organic compounds oxidized to $\mathrm{CO}_{2}$ can be seen in Fig. 4b, where the evolution of total organic carbon can be observed during the electrolysis. In all cases, the amount of carbon oxidized to $\mathrm{CO}_{2}$ is low and only $10 \%$ of the carbon is completely oxidized.

Similar electrolyses of phenol have been performed in a filter press with separation of the compartments, using a cationic membrane as separator, in order to avoid the reduction of the oxidation products of phenol. Figure 5a shows the evolution of the phenol concentration with the amount of charge during the electrolysis. The result obtained is very similar to the oxidation in a single compartment with respect to the order of the electrocatalytic activity. The most active electrode for phenol oxidation is the $\mathrm{Ti} / \mathrm{SnO}_{2}-\mathrm{Sb}-\mathrm{Pt}(3 \%)$ and the amount of phenol eliminated is similar in both cases (around 60\%). The electrode $\mathrm{Ti} / \mathrm{SnO}_{2}-\mathrm{Sb}$ presents a lower activity, however the amount of phenol eliminated with this electrode is higher $(38 \%)$ than the phenol oxidized in the singlecompartment setup (34\%). The electrode with the highest amount of platinum shows the lowest activity. Figure $5 \mathrm{~b}$ shows the evolution of TOC during the electrolysis of phenol with the different anodes. The amount of TOC eliminated with the $\mathrm{Ti} / \mathrm{SnO}_{2}-\mathrm{Sb}$ anode $(27 \%$ removed) is higher than the TOC removed with the singlecompartment cell ( $8 \%$ removed). These results indicate that phenol can be completely oxidized in successive step to $\mathrm{CO}_{2}$. The TOC removal is low using platinum-containing electrodes and the results are similar to that obtained in a single-compartment cell. This result can be interpreted due to the formation of a refractory organic compound for its oxidation to $\mathrm{CO}_{2}$ on platinum-containing electrodes such as carboxylic acids. ${ }^{5}$

The enhanced electrocatalytic activity for the phenol oxidation of the $\mathrm{Ti} / \mathrm{SnO}_{2}-\mathrm{Sb}-\mathrm{Pt}(3 \%$ atom $)$ is discussed in the following. As a general rule, the electrodes having a high overpotential for oxygen evolution have a better performance in oxidation of organic compounds ${ }^{10}$ due to the generation of a weakly bonded (physisorbed) hydroxyl radical on electroactive sites of the oxide layer (known as "nonactive" oxides). The high concentration of $\mathrm{OH}^{-}$radicals around the electrode promotes the complete oxidation of organic compounds. ${ }^{25,28}$ Typical layers employed in the elimination of organic compounds have this characteristic, for example, $\mathrm{SnO}_{2}$ or $\mathrm{PbO}_{2}{ }^{1,11,23,29}$ The introduction of platinum in the oxide layer decreases the overpotential for OER and, therefore, the electrocatalytic performance in organic oxidation decreases according to the increase of "active" sites for hydroxyl radicals. ${ }^{25}$ In fact, the electrodes containing platinum (13 atom \%) have a lower efficiency for elimination of phenol, in good agreement with the presence of a higher concentration of chemisorbed $\mathrm{OH}^{*}$ radicals. Consequently, the activity for the elimination of phenol with $\mathrm{Ti} / \mathrm{SnO}_{2}-\mathrm{Sb}-\mathrm{Pt}$ ( 3 atom\%) electrodes would be lower than the efficiency obtained with the electrode without platinum but better than the $13 \%$ platinum-doped electrode. The results showed that the best performance was obtained with the former electrode $(3 \% \mathrm{Pt})$.

The previous analysis has been performed attending only to electronic factors of the electrocatalysis (chemical composition of the electroactive layers), but morphologic factors also govern the electrocatalytic performance of the electrodes employed in the elimination of organic compounds with simultaneous production of oxygen. Bock and MacDougall have performed the anodic oxidation of $p$-benzoquinone with metallic oxide electrodes. ${ }^{27}$ These authors show that the elimination rate is related to the amount of easily accessible electroactive sites. Electrodes with high porosity, that is, electrodes with high inner surface, present lower values of current efficiency for organic destruction because OER occurs at inner and outer sites of the oxide, while the oxidation of organics occurs predominantly in the external surface sites of the oxide.

The analysis of the morphologic features of these electrodes was performed in a previous paper in which the electrochemical porosity of the different electrodes used in this work was determined and it was related to the morphology of the electrodes. ${ }^{20}$ The electrochemical porosity was obtained from an analysis of voltammetric charge similar to that performed by Trasatti and co-workers. This type of analysis has been usually employed for the analysis of oxide layers of metallic compounds such as $\mathrm{RuO}_{2}, \mathrm{Co}_{3} \mathrm{O}_{4}$, or $\mathrm{IrO}_{2}$, that is, oxides where there are a range of different oxidation states for the metallic compound (typically "active" sites). ${ }^{30-32}$ This method has been successfully employed for the electrochemical determination of morphologic information in our electrodes as shown in a previous paper, although the electrode without platinum is considered to be a "nonactive" electrode. ${ }^{20}$ The active sites are considered as local zones on the oxide surface with higher conductivity (i.e., higher Sb doping levels), and therefore the change of electronic charge during the voltammetric experiments is faster in those sites of the electrode. The concentration of hydroxyl radical during the electrolysis of wa- 


\begin{tabular}{|c|c|c|c|}
\hline \multicolumn{4}{|c|}{ 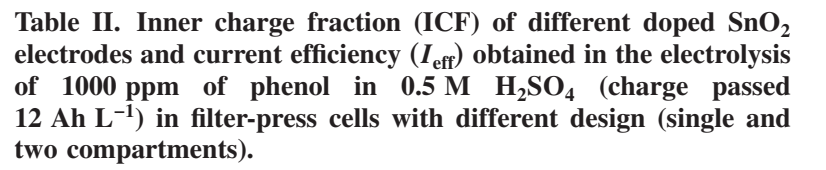 } \\
\hline \multirow[b]{2}{*}{ Electrode } & \multirow[b]{2}{*}{ ICF } & \multicolumn{2}{|c|}{$I_{\text {eff }} \%$} \\
\hline & & $\begin{array}{c}\text { Single } \\
\text { compartment }\end{array}$ & $\begin{array}{c}\text { Two } \\
\text { compartments }\end{array}$ \\
\hline $\mathrm{Ti} / \mathrm{SnO}_{2}-\mathrm{Sb}$ & 0.16 & 0.65 & 0.72 \\
\hline $\mathrm{Ti} / \mathrm{SnO}_{2}-\mathrm{Sb}-\mathrm{Pt}(3$ atom $\%)$ & 0.22 & 1.25 & 1.04 \\
\hline $\mathrm{Ti} / \mathrm{SnO}_{2}-\mathrm{Sb}-\mathrm{Pt}(13$ atom $\%)$ & 0.40 & 0.49 & 0.32 \\
\hline
\end{tabular}

ter must be higher around these regions of the electrode because there exists a higher local charge or surface conductivity (that is, a site for the physisorption of an $\mathrm{OH}^{*}$ radical).

From the extrapolation for low scan rate $(v \rightarrow 0)$, the total voltammetric charge $\left(q_{T}^{*}\right)$ was obtained, related to the total amount of electroactive sites. Plotting the voltammetric charge for high scan rates and from the extrapolation for $v \rightarrow \infty$, the outer voltammetric charge $\left(q_{o}^{*}\right)$ can be obtained, that is, the charge related with more accessible electroactive sites. The inner voltammetric surface $\left(q_{i}^{*}\right)$ is calculated as the difference $\left(q_{T}^{*}-q_{o}^{*}\right)$ and it is related with the electroactive sites less accessible for the electrolyte (i.e., cracks). Table II shows the ratio $q_{i}^{*} / q_{T}^{*}$ [inner charge fraction (ICF)] obtained for the electrodes studied in this work. The value of ICF drops when the amount of platinum in the oxide layer decreases. By scanning electron microscopy, it has been previously observed that the introduction of platinum on the oxide layer produces a compacting effect in the morphology of the layer. The electrodes containing platinum show a smoother and compacter surface. ${ }^{20}$

The ratio ICF is also called "electrochemical porosity." 30 The last term can be misinterpreted because electrodes with high values of "electrochemical porosity" present a less cracked surface while electrodes with low "electrochemical porosity" have more cracks on the surface. For that reason, the ICF concept fits better with compactness of the outer electrode surface.

Table II shows the values of current efficiency $\left(I_{\text {eff }}\right)$ for the elimination of phenol calculated as in the paper by Bock and MacDougall, ${ }^{27}$ assuming that only one electron is involved in the anodic oxidation of phenol, at the end of the electrolysis run (around $\left.12 \mathrm{Ah} \mathrm{L}^{-1}\right)$, calculated by means of

$$
I_{\text {eff }}=\frac{[C(0)-C(t)] V n}{I \Delta t}
$$

where $C(0)$ and $C(t)$ are the initial and final phenol concentration (molar units), $V$ is the volume of the cell $\left(\mathrm{dm}^{-3}\right), I$ is the applied current (A), $\Delta t$ is the electrolysis time (s), and $n$ is the number of electrons for the oxidation of phenol (assumed to be 1 because the oxidation mechanism is not well known)

The electrode with higher current efficiency is the $\mathrm{Ti} / \mathrm{SnO}_{2}-\mathrm{Sb}-\mathrm{Pt}(3$ atom\%). The synergetic effect in phenol elimination is a balance of two opposite effects: the higher compactness level of this electrode compared with the Sb-doped electrode favors the oxidation of phenol, although paying attention only to electronics factors, the electrocatalytic performance for this reaction would be poorer. The first effect is predominant for this electrode because the amount of platinum is low. In electrodes with higher amounts of platinum (13 atom \% concentration), electronics effects are much more evident.

In conclusion, electrodes of $\mathrm{Ti} / \mathrm{SnO}_{2}-\mathrm{Sb}-\mathrm{Pt}(3 \%)$ present a high electrocatalytic activity for the elimination of phenol in water. Antimony-doped tin dioxide electrodes present higher efficiency in the removal of products coming from phenol oxidation to $\mathrm{CO}_{2}$ (TOC removal), however these electrodes have the disadvantages of its low stability in anodic polarization conditions. Platinum
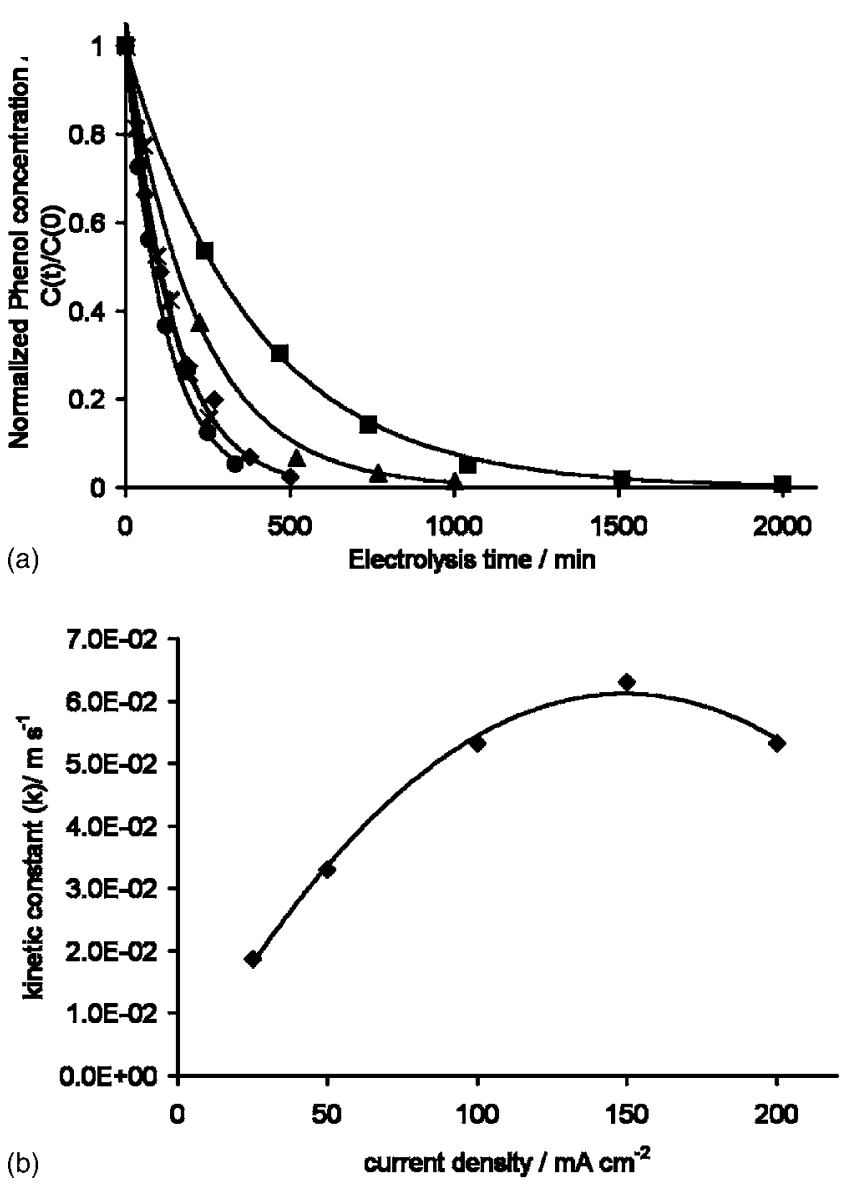

Figure 6. (a) Evolution of the normalized phenol concentration vs electrolysis time in the electrolysis of a $1000 \mathrm{ppm}$ phenol $+0.5 \mathrm{M} \mathrm{H}_{2} \mathrm{SO}_{4}$ solution in a two-compartment filter-press cell. Anode: $\mathrm{Ti} / \mathrm{SnO}_{2}-\mathrm{Sb}-\mathrm{Pt}(3$ atom \%), cathode: stainless steel. Current density: square points $(\mathbf{\square}) 25 \mathrm{~mA} \mathrm{~cm}^{-2}$, triangle points $(\mathbf{\Delta}) 50 \mathrm{~mA} \mathrm{~cm}^{-2}$, rhombus points $(\bullet) 100 \mathrm{~mA} \mathrm{~cm}^{-2}$, circle points (@) $150 \mathrm{~mA} \mathrm{~cm}^{-2}$, asterisk points (*) $200 \mathrm{~mA} \mathrm{~cm}^{-2}$. (b) Variation of the first-order kinetic constant for phenol elimination for the different current densities of (a).

(3 atom \%)-doped electrodes have a service life two orders of magnitude longer. ${ }^{20}$ For that reason, the optimization of the elimination conditions will be performed with this last electrode.

Electrochemical oxidation of phenol with $\mathrm{Ti}_{\mathrm{SnO}} \mathrm{S}-\mathrm{Sb}-\mathrm{Pt}$ (3\%) electrodes. - A systematic study of the electrolysis conditions for phenol elimination in $0.5 \mathrm{M} \mathrm{H}_{2} \mathrm{SO}_{4}$ solution has been performed with the $\mathrm{Ti} / \mathrm{SnO}_{2}-\mathrm{Sb}-\mathrm{Pt}$ (3\%) electrode attending to several factors such as current density, phenol initial concentration, separation of the compartments, etc.

The effect of current density in phenol elimination is shown in Fig. 6. The figure shows the evolution of phenol normalized concentration vs the electrolysis time (Fig. 6a) for current densities ranging from 25 to $200 \mathrm{~mA} \mathrm{~cm}^{-2}$. The experimental data can be properly adjusted to a first-order exponential decay, indicating a first-order kinetic for phenol concentration

$$
C(t)=C(0) \exp \left(-\frac{k A}{V} t\right)
$$

where $C$ is the phenol concentration, $A$ is the anode area $\left(\mathrm{m}^{2}\right), V$ is the volume $\left(\mathrm{m}^{3}\right)$ of the anolyte, $t$ is the electrolysis time (s), and $k$ is the kinetic constant for phenol elimination $\left(\mathrm{m} \mathrm{s}^{-1}\right)$. Figure $6 \mathrm{~b}$ shows the values of the kinetic constant as a function of the applied current density. The value of this constant increases with current density reaching a maximum around $150 \mathrm{~mA} \mathrm{~cm}^{-2}$, and then it decreases. 


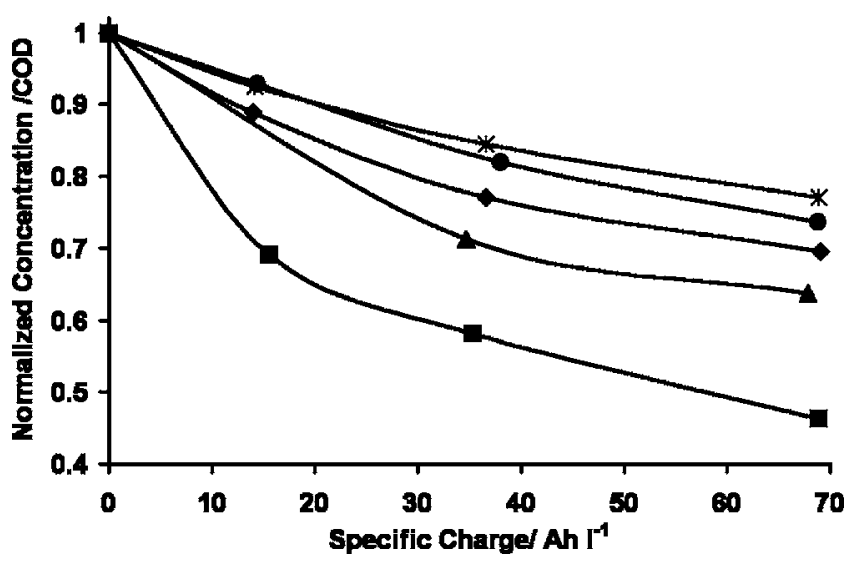

Figure 7. (a) Evolution of the normalized COD vs specific charge in the electrolysis of a $1000 \mathrm{ppm}$ phenol $+0.5 \mathrm{M} \mathrm{H}_{2} \mathrm{SO}_{4}$ solution in a twocompartment filter-press cell. Anode: $\mathrm{Ti} / \mathrm{SnO}_{2}-\mathrm{Sb}-\mathrm{Pt}(3$ atom \%), cathode: stainless steel. Current density: Square points (ם) $25 \mathrm{~mA} \mathrm{~cm}$, triangle points $(\boldsymbol{\Delta}) 50 \mathrm{~mA} \mathrm{~cm}{ }^{-2}$, rhombus points $(\bullet) 100 \mathrm{~mA} \mathrm{~cm}{ }^{-2}$, circle points (๑) $150 \mathrm{~mA} \mathrm{~cm}{ }^{-2}$, asterisks points (*) $200 \mathrm{~mA} \mathrm{~cm}^{-2}$.

Therefore, the optimal current density in terms of the shortest time for elimination of phenol is around $150 \mathrm{~mA} \mathrm{~cm}^{-2}$.

For the evaluation of the current efficiency for the nonselective oxidation of organic compounds (phenol + intermediate products) to $\mathrm{CO}_{2}$, a global parameter has been measured during the electrolysis runs, namely, the chemical oxygen demand. Figure 7 shows the evolution of the normalized COD of the solution vs the amount of charge passed during the electrolysis of a solution of $1000 \mathrm{ppm}$ of phenol at several current densities ranging from 25 to $200 \mathrm{~mA} \mathrm{~cm}^{-2}$. The instantaneous current efficiency (ICE) for this oxidation can be calculated using the relation ${ }^{5}$

$$
\mathrm{ICE}=\frac{\left[\mathrm{COD}_{t}-\mathrm{COD}_{t+\Delta t}\right] F V}{8 I \Delta t}
$$

where $\mathrm{COD}_{t}$ and $\mathrm{COD}_{t+\Delta t}$ are the chemical oxygen demand (in grams of $\mathrm{O}_{2}$ per $\mathrm{dm}^{3}$ ) at times $t$ and $t+\Delta t, I$ is the applied current (A), $F$ is the Faraday constant $\left(96,485 \mathrm{C} \mathrm{mol}^{-1}\right)$, and $V$ is the volume of electrolyte $\left(\mathrm{dm}^{3}\right)$. Figure 8 (inset) shows the evolution of the ICE vs the specific charge passed during the electrolysis of a phenol $1000 \mathrm{ppm}$ solution at $100 \mathrm{~mA} \mathrm{~cm}^{-2}$. The ICE drops during the electrolysis time as the concentration of organic decreases, due to the decreasing limiting current for the oxidation process or to the for-

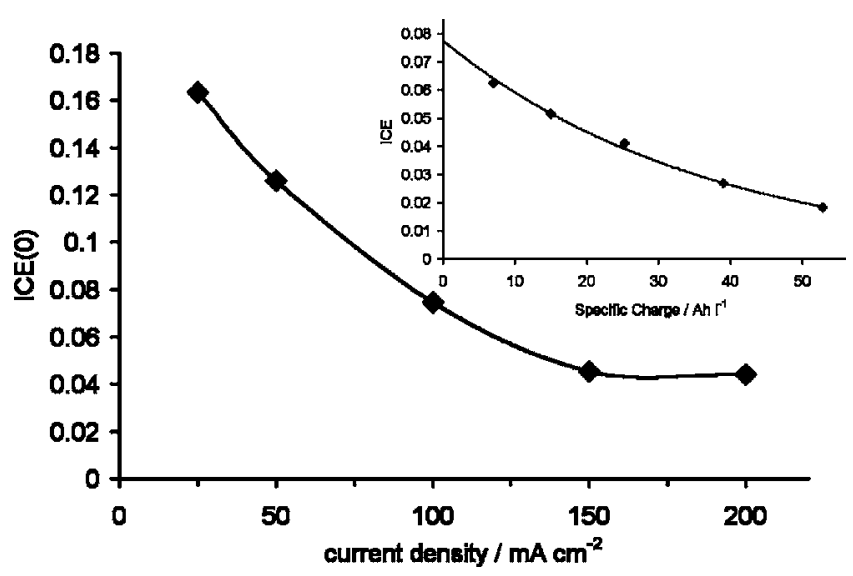

Figure 8. Variation of the initial instantaneous current efficiency, $\operatorname{ICE}(0)$, at different current densities in a solution of 1000 ppm of phenol. Inset: Evolution of the ICE obtained from COD during the electrolysis at $100 \mathrm{~mA} \mathrm{~cm}{ }^{-2}$.

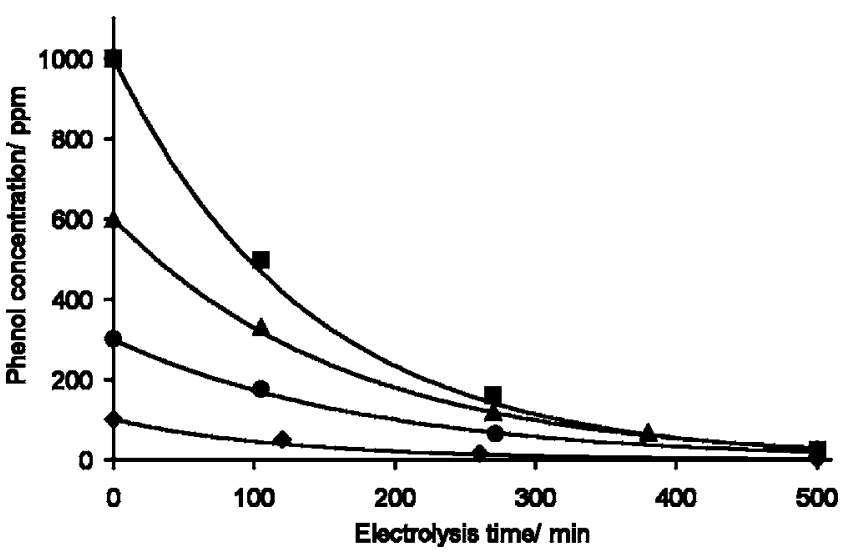

Figure 9. Electrolysis of solutions of phenol of different initial concentration in $0.5 \mathrm{M} \mathrm{H}_{2} \mathrm{SO}_{4}$ in a two-compartment filter-press cell. Anode $\mathrm{Ti} / \mathrm{SnO}_{2}-\mathrm{Sb}-\mathrm{Pt}$ (3 atom \%), cathode stainless steel. Evolution of the phenol concentration vs electrolysis time. Initial phenol concentration: Square points (ם) $1000 \mathrm{ppm}$. Triangle points $(\boldsymbol{\Delta}) 600 \mathrm{ppm}$. Circle points (๑) $300 \mathrm{ppm}$. Rhombus points $(\diamond) 100 \mathrm{ppm}$.

mation of refractory organic compounds toward anodic oxidation The evolution of ICE can be fitted to a first-order exponential decay function, similarly to the expression obtained for the evolution of ICE with diamond anodes

$$
\operatorname{ICE}(t)=\operatorname{ICE}(0) \exp (K t)
$$

where $K$ is a constant depending on the applied current density. ${ }^{33}$

From the extrapolation of the specific charge of the electrolysis to zero, the value of initial current efficiency, $\operatorname{ICE}(0)$, can be obtained. This value can be obtained for the different electrolysis conditions. The $\operatorname{ICE}(0)$ is plotted vs the current density in Fig. 8. The value of $\operatorname{ICE}(0)$ is high at low current densities values but it reaches a minimum at $150 \mathrm{~mA} \mathrm{~cm}{ }^{-2}$. A constant value of ICE(0) is obtained at higher current densities.

The effect of the initial concentration of phenol has been analyzed in the electrolysis of $1000,600,300$, and $100 \mathrm{ppm}$ phenol solutions. The evolution of phenol concentration during the electrolysis at $100 \mathrm{~mA} \mathrm{~cm}^{-2}$ in all cases fits well with a first-order exponential decay (Figure 9). More specifically, the value of the exponential factor is very similar in all the cases, indicating that the oxidation is produced in a similar manner for all the concentrations. The kinetic expression for phenol elimination for this concentration range [with $C(0)$ between 0 and $1000 \mathrm{ppm}$ of phenol] is

$$
C(t)=C(0) \exp \left[-(0.050 \pm 0.006) \frac{A}{V} t\right]
$$

With respect to the evolution of $\operatorname{COD}(\mathrm{t})$, the portion of the COD removed is $34-38 \%$ after passing a specific charge around $70 \mathrm{Ah} \mathrm{L}^{-1}$ in all the experiments performed with different initial concentration.

Finally, the effect of the separation of anolyte from catholyte (using a cationic membrane) has been studied by comparison of the results of the electrolysis of $1000 \mathrm{ppm}$ of phenol at $100 \mathrm{~mA} \mathrm{~cm}^{-2}$ in a cell with one or two compartments. From a technical point of view, single-compartment cells are preferred as they are easier to build and to arrange. In addition, the lower distance and fewer separator elements produce a lowering in the cost of the electrochemical process (lower ohmic drops). The evolution of the normalized phenol concentration during the electrolysis with a single- and a twocompartment cell is very similar in both cases. Thus after $12 \mathrm{Ah} \mathrm{L}^{-1}$ specific charge passed, the phenol removed in the separated cell is $55 \%$, while it is $58 \%$ for the single-compartment cell. With respect to the COD removal, the trend for both electrolyses is very similar, but the COD removed is slightly higher for the separated cell (17\%) with respect to the nonseparated cell $(14 \%)$. 


\section{Conclusions}

The electrolysis of aqueous solutions containing phenol has been performed with a variety of antimony and antimony-platinum-doped $\mathrm{SnO}_{2}$ electrodes of $\mathrm{Ti} / \mathrm{SnO}_{2}-\mathrm{Sb}$ and $\mathrm{Ti} / \mathrm{SnO}_{2}-\mathrm{Sb}-\mathrm{Pt}$ oxidized phenol at potential lower than the OER. When the amount of platinum increases in the electrode oxide layer, the oxidation potential of phenol decreases. During the first voltammetric scans, the oxidation of phenol suffers inhibition due to the electrode fouling by the formation of a polymeric film on the electrode surface which can be removed by anodic polarization.

Discarding geometric effects, the electrocatalytic activity (per active site) of the electrode $\mathrm{Ti} / \mathrm{SnO}_{2}-\mathrm{Sb}$ for phenol oxidation is higher than the activity of platinum-containing electrodes. The mechanism of the electrochemical oxidation of phenol at $1.8 \mathrm{~V}$ is similar for all the electrodes studied as evidenced by the potential step experiments.

The oxidation of phenol solutions was performed by electrolysis in galvanostatic conditions. The electrode $\mathrm{Ti} / \mathrm{SnO}_{2}-\mathrm{Sb}-\mathrm{Pt}$ ( 3 atom $\%$ ) has the highest efficiency for phenol removal by anodic oxidation. However, phenol is oxidized in the platinum-containing electrodes to organic species that remain in solution. The electrode $\mathrm{Ti} / \mathrm{SnO}_{2}-\mathrm{Sb}$ presents the best performance in the nonselective elimination of the organic compounds to $\mathrm{CO}_{2}$. Nevertheless, these electrodes have a very short service life. For that reason, the $\mathrm{Ti} / \mathrm{SnO}_{2}-\mathrm{Sb}-\mathrm{Pt}$ (3 atom \%) electrode is preferred for use in anodic oxidation of phenol.

The galvanostatic oxidation of phenol with $\mathrm{Ti} / \mathrm{SnO}_{2}-\mathrm{Sb}-\mathrm{Pt}(3$ atom \%) electrode shows a first-order kinetics with a kinetic constant $(k)$ depending of the applied current density. The highest value for $k$ was obtained for $150 \mathrm{~mA} \mathrm{~cm}$ c $^{-1}$ in the conditions employed in this work. The kinetic expression is very similar for the oxidation of phenol concentration ranging between 100 and $1000 \mathrm{ppm}$.

The current efficiency for the elimination of phenol and COD of the solution decreases as the applied current density grows, as expected. The oxidation of phenol in a single-compartment cell has a similar performance to the electrolysis in a separated (anolytecatholyte) cell.

\section{Acknowledgments}

Financial support by the Generalitat Valenciana (GRUPOS04/75 and GV05/136) and Ministerio de Ciencia y Tecnología (MAT200401479) projects are gratefully acknowledged.

\footnotetext{
Universidad de Alicante assisted in meeting the publication costs of this article.
}

\section{References}

1. F. Bonfatti, S. Ferro, F. Lavezzo, M. Malacarne, G. Lodi, and A. De Battisti, J. Electrochem. Soc., 146, 2175 (1999).

2. M. A. Rodrigo, P. A. Michaud, I. Duo, M. Panizza, G. Cerisola, and C. Comninellis, J. Electrochem. Soc., 148, D60 (2001).

3. A. R. Bowers, in Toxicity Reduction in Industrial Effluents, P. W. Lankford and W. W. J. Eckenfelder, Editors, Van Nostrand Reinhold, New York (1990).

4. V. S. Desucre and A. P. Watkinson, Can. J. Chem. Eng., 59, 52 (1981).

5. C. Comninellis and C. Pulgarin, J. Appl. Electrochem., 21, 703 (1991)

6. C. Comninellis and A. Nerini, J. Appl. Electrochem., 25, 23 (1995).

7. J. Iniesta, P. A. Michaud, M. Panizza, G. Cerisola, A. Aldaz, and C. Comninellis, Electrochim. Acta, 46, 3573 (2001).

8. P. Canizares, F. Martinez, M. Diaz, J. Garcia-Gomez, and M. A. Rodrigo, J. Electrochem. Soc., 149, D118 (2002)

9. M. Gattrell and D. W. Kirk, J. Electrochem. Soc., 140, 1534 (1993).

10. C. Comninellis and A. De Battisti, J. Chim. Phys. Phys.-Chim. Biol., 93, 673 (1996).

11. J. Iniesta, E. Exposito, J. Gonzalez-Garcia, V. Montiel, and A. Aldaz, J. Electrochem. Soc., 149, D57 (2002).

12. K. T. Kawagoe and D. C. Johnson, J. Electrochem. Soc., 141, 3404 (1994).

13. X. M. Chen, G. H. Chen, F. R. Gao, and P. L. Yue, Environ. Sci. Technol., 37, 5021 (2003).

14. M. Panizza, P. A. Michaud, G. Cerisola, and C. Comninellis, J. Electroanal. Chem., 507, $206(2001)$

15. C. Comninellis and C. Pulgarin, J. Appl. Electrochem., 23, 108 (1993).

16. S. Stucki, R. Kotz, B. Carcer, and W. Suter, J. Appl. Electrochem., 21, 99 (1991).

17. B. Correa Lozano, C. Comninellis, and A. Debattisti, J. Appl. Electrochem., 27, 970 (1997).

18. F. Vicent, E. Morallon, C. Quijada, J. L. Vazquez, A. Aldaz, and F. Cases, J. Appl. Electrochem., 28, 607 (1998).

19. R. Kotz, S. Stucki, and B. Carcer, J. Appl. Electrochem., 21, 14 (1991).

20. F. Montilla, E. Morallon, A. De Battisti, and J. L. Vazquez, J. Phys. Chem. B, 108, 5036 (2004).

21. F. Montilla, E. Morallon, A. De Battisti, A. Benedetti, H. Yamashita, and J. L. Vazquez, J. Phys. Chem. B, 108, 5044 (2004).

22. F. Montilla, E. Morallon, A. De Battisti, S. Barison, S. Daolio, and J. L. Vazquez, J. Phys. Chem. B, 108, 15976 (2004).

23. D. C. Johnson, J. Feng, and L. L. Houk, Electrochim. Acta, 46, 323 (2000)

24. G. Saracco, L. Solarino, R. Aigotti, V. Specchia, and M. Maja, Electrochim. Acta, 46, 373 (2000).

25. C. L. P. S. Zanta, P. A. Michaud, C. Comninellis, A. R. de Andrade, and J. F. C. Boodts, J. Appl. Electrochem., 33, 1211 (2003).

26. R. Lapuente, F. Cases, P. Garces, E. Morallon, and J. L. Vazquez, J. Electroanal. Chem., 451, 163 (1998).

27. C. Bock and B. MacDougall, J. Electroanal. Chem., 491, 48 (2000).

28. G. Foti, D. Gandini, and C. Comninellis, Curr. Top. Electrochem., 5, 71 (1997).

29. E. Brillas, R. M. Bastida, E. Llosa, and J. Casado, J. Electrochem. Soc., 142, 1733 (1995).

30. S. Ardizzone, G. Fregonara, and S. Trasatti, Electrochim. Acta, 35, 263 (1990).

31. L. A. DaSilva, V. A. Alves, S. Trasatti, and J. F. C. Boodts, J. Electroanal. Chem., 427, 97 (1997).

32. C. P. Depauli and S. Trasatti, J. Electroanal. Chem., 396, 161 (1995).

33. F. Montilla, P. A. Michaud, E. Morallon, J. L. Vazquez, and C. Comninellis, Electrochim. Acta, 47, 3509 (2002). 